\title{
市政公路工程施工技术控制与管理
}

\author{
付海波 \\ 中北交通建设集团有限公司 \\ DOI:10.18686/bd.v2i5.1370
}

[摘 要] 在交通越来越重要的今天, 公路建设也得到越来越多的重视, 公路工程的施工技术控制与管理方面的问题逐渐显 示出来,公路工程的施工技术控制和管理的水平关系着公路交通的安全水平,也与施工单位的经济效益挂钩,本文中,将对公 路工程施工技术控制与管理的重要性作出分析,并对做好公路工程技术控制与管理提出建议。

[关键词] 公路工程;施工技术; 控制与管理;管控策略

随着经济的高速发展, 各个领域的联系越来越密切,除 去互联网的沟通连接外, 四通八达的交通网络也作出了重 大贡献。社会发展对于交通网络的要求越来越高,这对公路 工程建设来说,可以获得更多更好的发展机会。公路工程施 工技术的控制水平以及管理质量与公路工程施工进度和工 程完成质量直接相关,因此,我们要将公路工程的施工技术 控制和管理问题提上日程。这样才能够保证公路工程保质 保量的完成。

1 做好公路工程施工技术控制和管理工作的重要性和 必要性

在公路工程的建设中, 施工技术的管理和控制设计工 作显的尤为重要, 做好这个工作, 能够为公路工程的建设带 来切实便利和经济利益,具体表现在以下几个方面。

1.1 有利于施工企业综合管理水平和竞争力的提高

公路工程的高速发展, 使其施工市场的竞争激烈程度 与日俱增。在这种情况下, 有些企业为了拿到工程, 在工程的 各个方面尽力压缩利润, 这样做确实能够在一定程度上提 高在同等级企业中的竞争力, 但这种方式不仅使企业的经 济效益有所降低, 还对工程的负责人及工人的积极性有所 打消。在这个时候,做好工程施工技术的管控, 不仅能够大幅 度提高企业或施工单位的市场竞争力, 还可以在一定程度 上使所获得的利润有所增加。

在公路工程的建设过程中, 将施工技术管理和控制工 作重视起来, 把这项工作做到正确合理, 能够更加合理的将 各种资源进行优化配置, 更加有效率对每个人的工作进行 分配, 更好的将施工单位本身拥有的技术力量体现出来。做 好公路工程施工技术的控制和管理很大程度上能够避免大 多数的质量问题和安全隐患, 在提高工程整体质量的同时, 还能够尽量的减少施工的成本, 让企业经济效益的增加得 到实现。

1.2 有利于提高施工质量,使施工进度有所保障

在公路工程的施工的过程中, 施工技术是作为指导工 作的核心而存在的, 将施工技术合理的管理和控制起来, 牢 牢的把握在手中, 再按照施工流程进行指导, 就可以很好的 将公路工程的建设完成。可以说,如果没有对施工技术的控
制和管理,整个施工团队的工作就像是无头苍蝇一样, 没有 效率,而且质量也无法保证。这个时候挑选一些具有管理才 能的核心人员, 将公路工程施工技术的控制和管理工作做 好,才是正确的选择!

1.3 有利于打造高素质的施工团队

一项公路工程高效完美的完成, 需要一支高素质的施 工队伍,优秀的施工队伍中,一定存在着优秀的管理者。由管 理者将施工技术合理的控制和管理起来, 用以指导施工团 队进行施工, 这样, 施工的其他人只需要听命令听管理就可 以保证工程的正常进行了。而一个企业要想拥有这样的管 理人才, 就必须要做好人才的培养及引进工作, 这样才能提 升整个施工队伍的综合素质,使工程完成得尽善尽美。

\section{2 公路工程施工技术控制和管理需要遵循的原则}

想要做好公路工程施工技术控制和管理工作, 除了需 要有高素质的管理人才之外,还需要遵循一些基本原则。

公路工程施工技术控制和管理需要具有科学性。公路 工程不仅仅指将公路铺设完成, 它还包括公路建设完成之 后的养护管理, 公路的路基路面, 经过的桥梁隧道, 排水系统 的设计, 路途周边的绿化, 交通监控设备设施的安装与维护, 这些都包括在公路工程的建设中。它涉及的方面很广, 层次 众多,于是在公路工程施工技术控制和管理上, 就需要注重 其科学性, 将方方面面都科学的安排合理, 以保证公路工程 的正常完成。

\section{1 成本节约的原则}

无论是公路工程施工技术的控制和管理, 还是其他的 一些什么方法, 都是为了降低公路工程施工中的成本, 以最 小的成本消耗来完成整个工程的建设。从短期来看, 无论是 公路的铺设, 还是周边设施的完善, 都是属于资源消耗而没 有收益的, 公路工程的收益主要是在后期长期利用中慢慢 积累的。而公路工程施工技术控制和管理,则需要本着节约 成本的原则, 在保证不影响公路后期使用的情况下完成公 路工程建设。

\section{2 注重细节原则}

在上文中说过, 公路工程建设涉及到方方面面, 在施工 过程中,需要注意到各方面的细节。于是公路工程施工技术 
的控制和管理,就需要以精细化管理的理念为指导,把细节 控制住,是公路工程施工技术的有效性得以保持。

\section{3 公路工程施工技术控制和管理的策略}

由于公路工程涉及的方面很广, 相应的其公路工程施 工技术的管理和控制工作难度也十分大, 为了工作的有效 展开,以下介绍几点工路工程施工技术管理和控制的策略。

\section{1 需要不断完善公路工程施工技术管理制度}

公路工程施工技术管理和控制，需要一套完善的制度， 来以技术规范和标准的方式去监督和规范施工工人的施工 行为,这是从总的方面来说。在具体实施方面,还要视不同的 情况具体分析。每个公路工程的情况都有所不同,所需要用 到的施工技术,其管理的难度,技术管理的特点和方案都是 有不同之处的。制度制定者需要做到的就是在与国家相关 部门对公路工程的要求不充突的情况下, 在具体情况具体 分析,尽力的完善公路工程施工技术管理制度的制定。在具 有明确的公路工程施工技术管理制度时, 需要管理者积极 宣传教育,使工人们对这个制度做到了解,然后,要严格要求 施工工人按照这个制度去进行工作, 这样才能很大程度上 提高公路工程施工的效率。

3.2 对图纸会审过程的控制和管理需要得到重视

对于公路工程设计图纸的重视, 是基于它对于整个公 路工程的重要性来说的。在每项工作工程开工前,都需要对 其设计图纸进行严格的会审,这个会审其实就是,考察这个 图纸的设计方案和实际施工完成后, 公路的目标实际效能 是否能够达到要求, 所以我们应该对这个会审过程进行控 制与管理。具体来讲,我们应该从以下三个方面来做好这项 工作。

3.2.1 要确定设计图纸的完善性和合法性。一份优秀的 设计图纸需要在公路工程涉及到的各个方面都作出设计和 设想,每一部分的信息都不能缺少。而且对于设计图纸最基 本的要求, 就是应该符合国家相关规定, 在不损害国家和地 方利益的前提下进行设计。

3.2.2 公路工程设计的重点区域,一定要得到重视。对于 公路工程的主结构和主部位的设计, 除了要符合国家的规 定外,还应该尽力的发挥设计的功能,使公路工程的建设能 够取得更多的效益。

3.2.3 对于图纸中需要用到的公路工程中施工需要的 技术装备,应该与实际生产需求相互吻合,这样才能保证公 路工程的质量。严格执行相关的验收规范和标准,确保工程
质量。

\section{3 技术控制管理部门的组建和专业化}

在公路工程施工技术控制和管理上, 我们有了建立健 全的管理制度, 有了设计合理优秀的设计图纸, 还需要一些 专门的人才, 来进行公路工程施工技术控制和管理工作的 开展, 这样才能够使好的制度和好的图纸得到更好的利用, 实现公路工程施工技术管理和控制工作的功能。为此,我们 最好是建立一个专门的部门。建立这个部门需要做到的是:

3.3 .1 要将它从其他各部门独立出来, 赋予其足够的权 限, 明确它所能管理的范围,使这个部门能够在规定范围内, 做好公路工程施工技术的控制与管理。

3.3.2 这个部门中的各种人才需要进行专门的培训和 教育, 最大程度上提升他们的专业才能, 同时还要对其职业 道德进行考察和提高, 这样才能够保证这个部门能够切实 有效的,将公路工程各施工技术控制和管理工作做好。

3.3.3 这个部门需要有严格的考核机制, 不仅对本部门 内的人员进行专业知识和管理才能的考察, 还要对其职业 道德等进行考察。将考察评定的结果与他们的薪酬进行挂 钩, 这样能够, 很大程度上激发他们的工作积极性和学习积 极性。

\section{4 结束语}

社会一直没有停下进攻和发展的步伐, 公路工程的发 展机遇也一直都在增加。公路工程的发展也是越来越快, 它 是关系到国民经济和我们切实利益的, 我们需要它在迅速 发展的同时,保质保量的完成公路工程建设。而公路工程施 工技术控制和管理就是做到这一点所可以借助的捷径。公 路工程施工技术控制和管理体系的构建, 需要长时间一点 一滴的积累完善,对于负责这些的管理者来讲,他们不能够 急于求成,而应该在发展过程中, 不断的发现缺点改正缺点, 这样一步步的完善公路工程施工技术控制和管理体系,让 公路工程施工技术和管理朝着更高的水平发展和进步。

\section{参考文献:}

[1] 杨帆. 关于公路工程施工技术控制与管理的分析 [J].智能城市,2017,3(06):160.

[2]赵欣欣.公路工程施工技术控制与管理对策和施工 [J].交通世界,2016,(14):116-117.

[3]石飞翔.关于公路工程施工技术控制与管理的分析 [J].中外企业家,2015,(30):93-94. 